ISSN: 0514-7336 — ISSN electrónico: 2386-3943

DOI: https://doi.org/10.14201/zephyrus202187197207

\title{
ON AN UNUSUAL FEMALE HEAD FROM ITALICA (SANTIPONCE, SEVILLE)
}

\section{Una peculiar cabeza femenina procedente de Italica (Santiponce, Sevilla)}

\author{
David OJEDA \\ Dpt. of History of Art. Faculty of Geography and History-UNED. Paseo Senda del Rey, 7. 28040 Madrid. Correo-e: \\ dojeda@geo.uned.es.ORCID ID: https://orcid.org/0000-0001-5379-8069
}

Recepción: 19/07/2020; Revisión: 4/03/2021; Aceptación: 16/04/2021

Aвstract: A previously unpublished female head, which decorated the residential area of the Hadrianic extension of Italica, was found in excavations carried out by A. Parladé in 1929/1930 in the proximity of the House of the Neptune Mosaic. Its most particular characteristic is that the upper part was formed by a separately worked segment of hair. This head is the first to be documented in Hispania made with this technique, in which a tenon is located in the back of the head. As it is an unusual technique, other examples in the Empire of similar characteristics are detailed in a list. Finally, a series of arguments are given to date the object in the second quarter of the $2^{\text {nd }}$ century $\mathrm{AD}$ and include it in the group of ideal heads made during that time in Italica.

Key words: Hispania; Roman Portrait; Ideal Sculpture; Assemblage; Hair Segments.

Resumen: El objetivo de este trabajo es presentar una cabeza femenina inédita, que decoró la zona residencial de la ampliación adrianea de Italica. Fue hallada en las excavaciones realizadas en 1929/1930 por A. Parladé en las inmediaciones de la Casa del Mosaico de Neptuno. Su característica más destacada es que su parte superior fue realizada mediante un segmento de pelo trabajado por separado. La cabeza italicense permite documentar por primera vez en Hispania una pieza realizada por medio de esta técnica, en la que la espiga está labrada en la parte trasera de la cabeza. Dado que el sistema es poco habitual, se han buscado otros paralelos en el Imperio con características similares. Finalmente, se plantean una serie de argumentos que permiten datar la pieza en el segundo cuarto del s. II d. C. e incluirla dentro del grupo de las cabezas ideales italicenses realizadas en ese intervalo cronológico.

Palabras clave: Hispania; retrato romano; escultura ideal; ensamblaje; segmentos de pelo.

\section{Introduction ${ }^{1}$}

A female head in the Archaeological Museum of Seville -Inv. no. CE 4727- has remained unstudied although it was found nearly 100 years

I would like to thank J. Ch. Balty, D. Boschung, M. Cadario, K. Fittschen, and E. Rosso for their valuable help. Thanks to the kindness of Archaeological Museum of Seville, it was possible to perform the autopsy and offer the photographs of this female head. $\mathrm{ago}^{2}$. According to the museum registry books, it entered the museum in 1931. Its provenance is not given but I thought that it might have been found in Italica in that year. Bearing in mind

2 The case of the female head studied here is not unique. Numerous unstudied sculptures are held in the stores of Seville Archaeological Museum. Others have been published in recent years, such as those made known by Peña (2004: 63-102, figs. 1-10; 2005: 137-162, figs. 6 and 8-9) and Ojeda (2019: 852-854, fig. 3). 


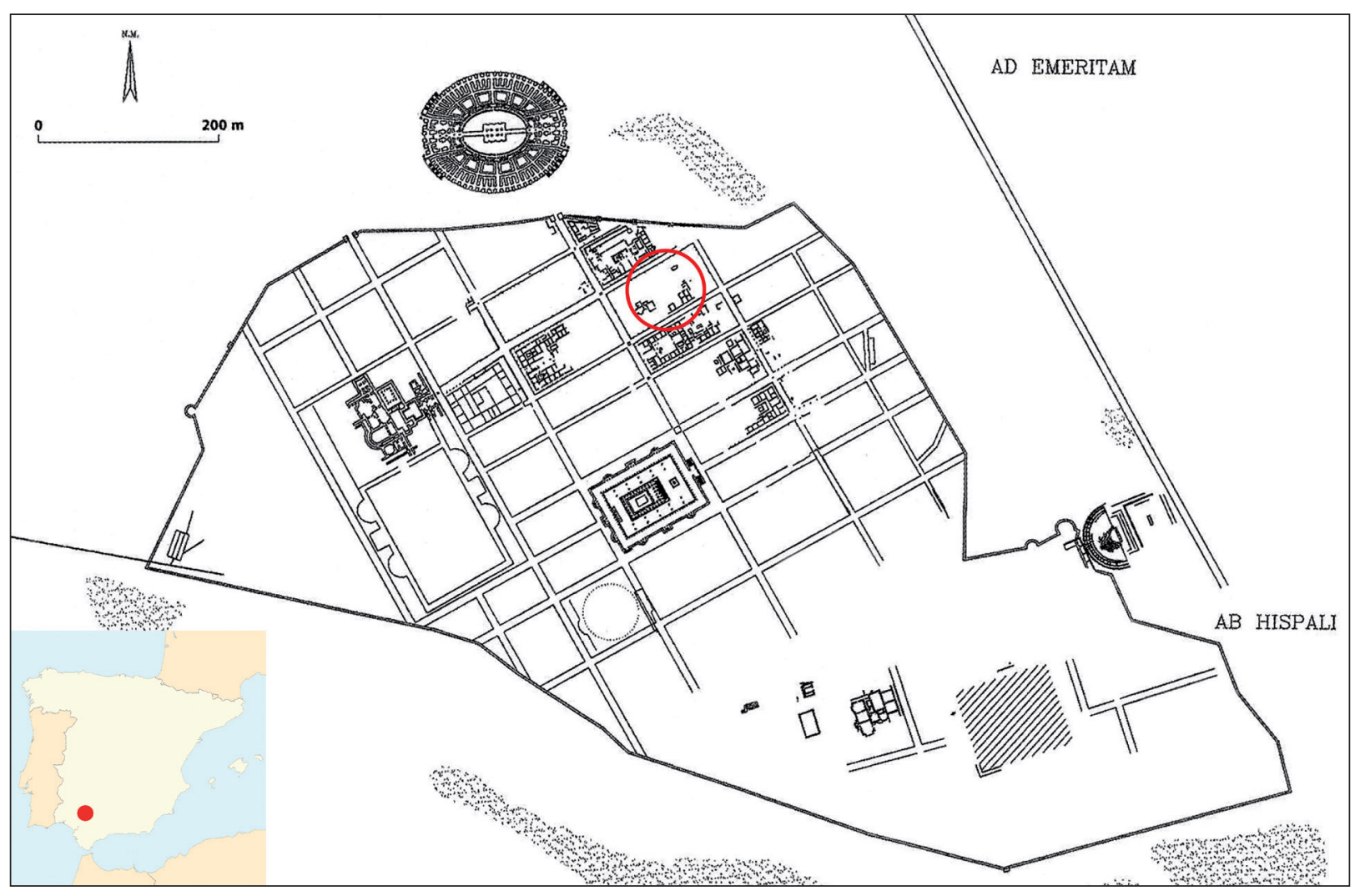

FIG. 1. Location of Italica in the Iberian Peninsula and plan of the Nova Urbs; the circle marks the findspot of the female head.

that the director of the excavations at Italica from 1919 to 1933 was A. Parladé ${ }^{3}$, it seemed possible to find the head in his reports.

Consulting Parladé's reports on his excavations in Italica showed that it was found in the archaeological works in 1929/1930. He describes the place and time of the discovery in the following way:

... I am now excavating a very large public building, apparently other baths, very near to the last house to be described - no. 3. Few objects of little value have been found: two capitals of white marble, four shafts of marble columns, including a large one of fine marble that might have belonged to a public building that is perhaps hidden in the surroundings; a lovely head of a woman (Minerva?) with a tenon of the same block of marble in the upper part of the head that may have held a helmet of bronze or

3 For this aristocrat, the third Count of Aguiar, from Málaga: Caballos et al., 1999: 48. another metal when it was separated from the bust. Four glass dies, three of them with busts of men and one with adornments; some pottery jars, pieces of Numantine clay, marble mouldings and architectural fragments; some glass lachrymatories and many copper coins of different periods, etc., etc...

(Parladé, 1934: 12)

Therefore, the head was found in a building in Italica (Fig. 1), which Parladé situates near House no. 3. The plans in the report allow identifying this Roman domus ${ }^{4}$, which is now known as the House of the Neptune Mosaic. It is a large domus occupying a block about $6,000 \mathrm{~m}^{2}$ in size and that still today is only partially excavated. Despite this, it has been shown to contain rooms that are richly paved with mosaics (Mañas, 2011: 28-29) and remains of baths (García-Entero, 2005: 718-719)

4 Parladé (1934): "Plano A. Plano de los descubrimientos efectuados en la ciudad de Itálica. Durante el año 1930". 
with the Neptune mosaic that gives its name to the house.

This information demonstrates that the head came from the urban enlargement of Italica in the time of Hadrian, corresponding to the so-called Nova Urbs5. Unfortunately, no more precise data about the archaeological context is available, as Parladé did not draw plans of the building where the head was found or provide more precise details about the location of the find. Therefore, it can only be said that it was discovered in the proximity of the House of the Neptune Mosaic. As this was a residential part of Italica, it is likely to have formed part of the decoration of one of the domus in the area ${ }^{6}$.

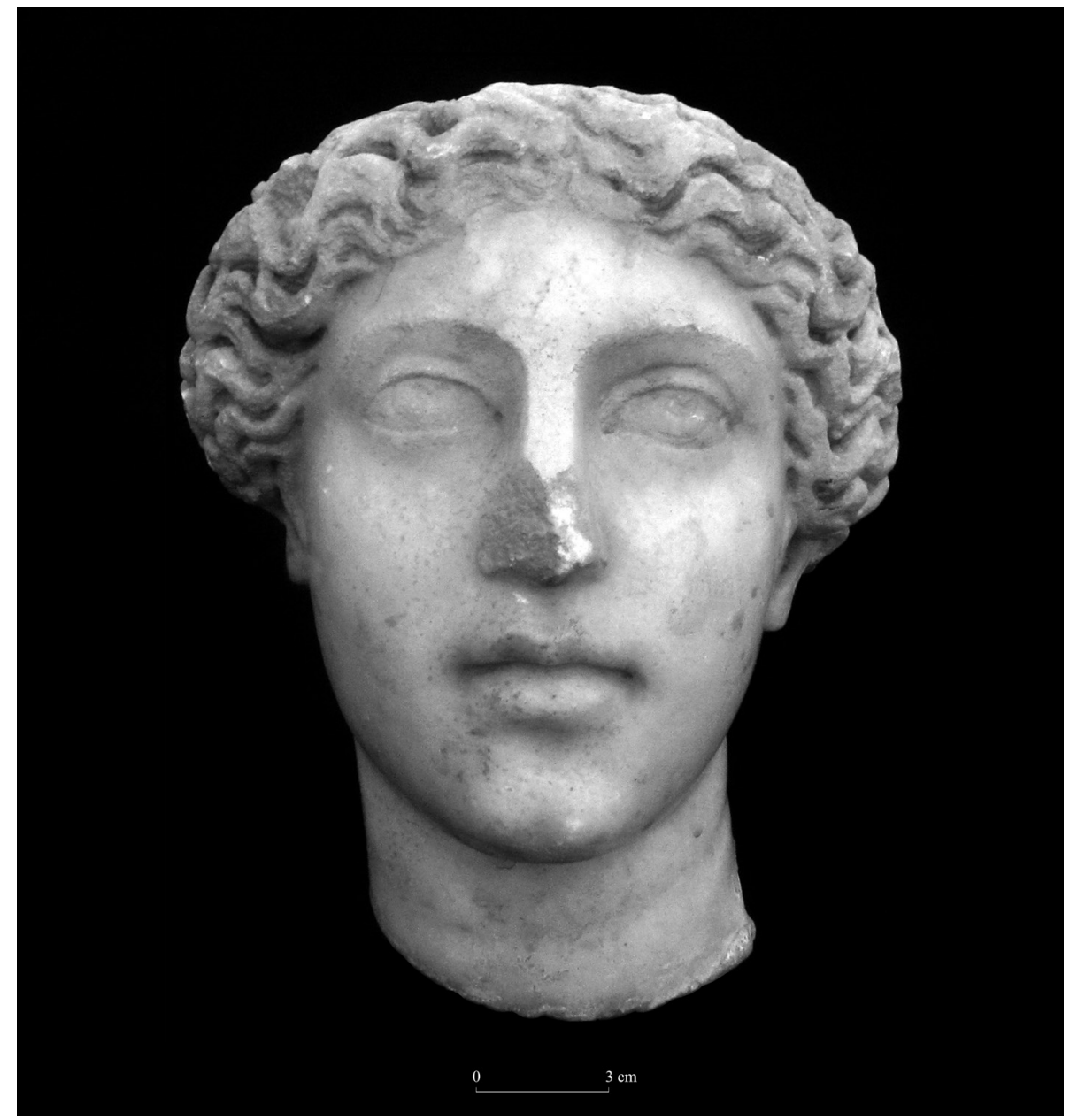

FIG. 2. Frontal view of the female head from Italica; height $18 \mathrm{~cm}$, distance from chin to cranium $14 \mathrm{~cm}$; Archaeological Museum of Seville 4727.

\section{Description and comparative analysis of the head}

The maximum height conserved of the head is $18 \mathrm{~cm}$, with a distance from chin to skull of $14 \mathrm{~cm}$,

5 This term was coined by García y Bellido (1960: 7374). On the Hadrianic extension of Italica see the study of León (1992).

6 It is not totally certain, but it cannot be ruled out that the head belonged to the decoration in the House of the Neptune Mosaic. Parladé describes the building where the head was found as a space used for baths. It has later been documented that this domus possessed an area of about $500 \mathrm{~m}^{2}$ on its western side that was used for baths. This implies that perhaps it was in that area where Parladé found the head. and its most noticeable flaw is the fracture of the nose (Figs. 2-5). The back of the head is not broken but prepared to receive a separately worked segment of hair ${ }^{7}$. With this aim, the sculptor shaped a rounded surface with incisions and a circular tenon of the same piece of marble at the back. The circular surface of the back of the head is $15 \mathrm{~cm}$ in diameter and the tenon is $5 \mathrm{~cm}$ in diameter. The

It is not known why the workshops used this technique and the sources do not provide any information that might help. For possible reasons for its use: Schäfer, 2015: 757-761. For heads made in separate parts, the first systematic and still essential study is that of Crawford, 1917; for this problem, see most recently Papini, 2019: 168-177, no. 8. 


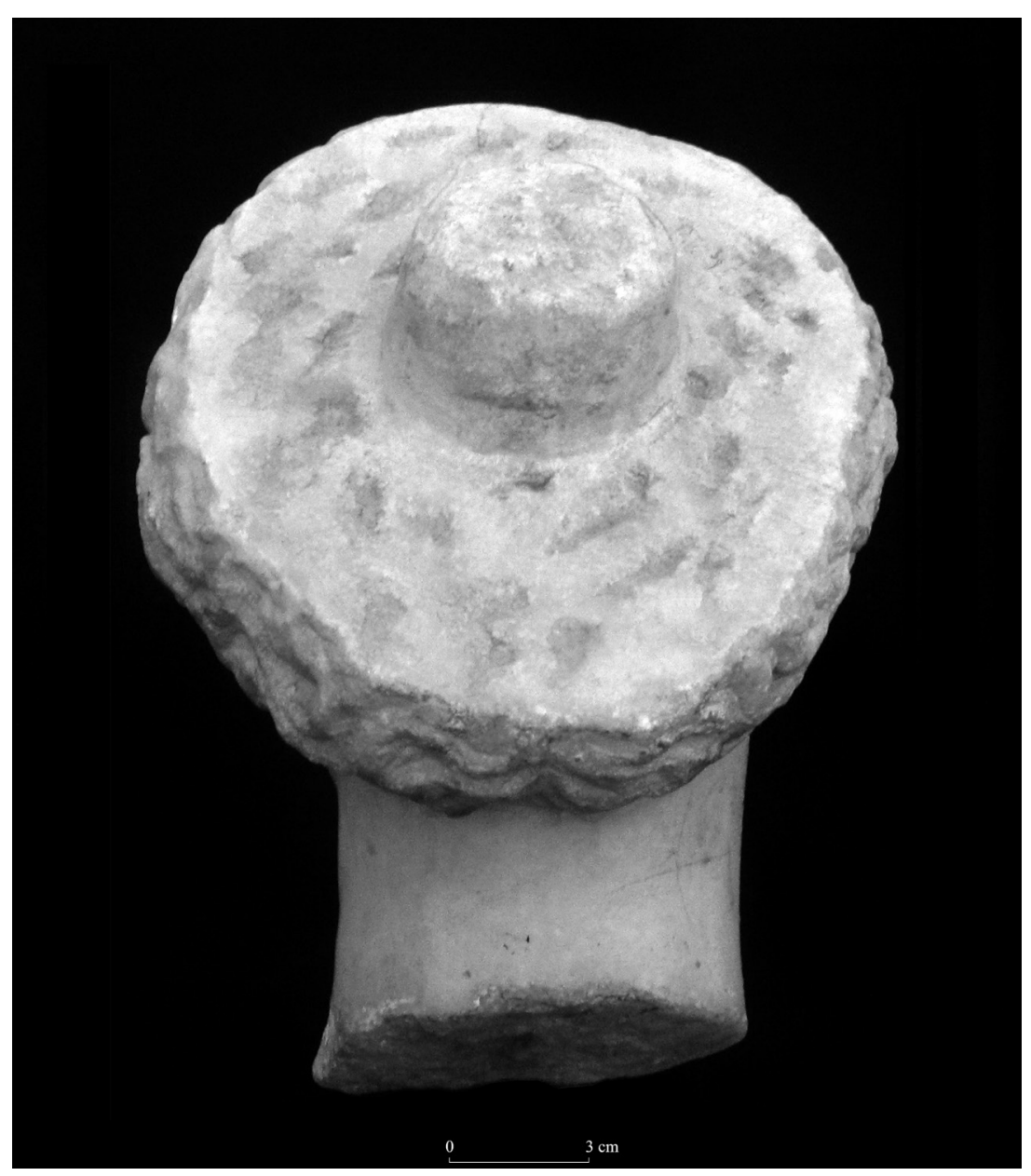

FIG. 3. Back of the female head from Italica.
This head from Italica cannot be included in the group of Roman portraits with a wig ${ }^{10}$, or in the group of portraits with 'Perücken"11. Instead, it belongs to the Roman heads with separately worked segments of hair. The three types of figures are similar, which may cause some confusion when identifying them. They can be differentiated by the following criteria:

- Roman portraits with a wig are made from a single piece and the wig is placed directly on the natural hair of the portrayed person. They are easily recognisable because the locks of natural hair extend below the false hair. This system has so far only been documented in female portraits ${ }^{12}$.

- Roman portraits with 'Perücken' are made with two pieces: one that corresponds to the lower part of the head and one that is a separately carved piece that forms the whole of the hair. Although most of the known cases are female figures $^{13}$, a male one is also known ${ }^{14}$. attachment to be inserted in the back has not been found, but it must have possessed a circular socket in its lower part to be fitted on the tenon. Some type of adhesive would probably have been used to fasten the two pieces more securely ${ }^{8}$. To facilitate the adhesion, the sculptor made small incisions in the smooth and rounded surface of the head'.

8 On the use of adhesives in Antiquity, see the works of Adam (1966: 80-82), Stern (1985: 407-408), Claridge (1990: 153-154) and Schäfer (1996: 56).

9 For the combination of adhesives and tenons in Greco-Roman heads: Ojeda, 2018a: 200-201.
10 See most recently, Ackers, 2019.

11 Fittschen and Zanker, 1983: 105-106. Fittschen, 2005 with previous bibliography.

12 For an example of a female portrait with a wig: Fittschen and Zanker (1983: 96-97, no. 140, figs. 165-167).

13 For an example of a female portrait with a 'Perücke': Fittschen and Zanker (1983: 83, no. 113, fig. 143). The most complete list of portraits with 'Perücken' is in Fittschen and Zanker (1983: 105-106, n. 4), whose list can be completed with Fittschen (2005: 90, n. 23). Previous literature on this topic can be found in both works.

14 Museum of Fine Arts de Boston -Inv. no. 2004.2232-. It has not been published but appears in the museum's on-line catalogues. 
- Roman heads with separately worked segments of hair are usually made with two pieces, although there are examples where it can be seen that a large number of attachments was employed ${ }^{15}$. In these cases, a portion, or several portions, of hair were made separately to be fitted later and thus complete the figure's hair. This technique has been documented in female portraits ${ }^{16}$, male portraits ${ }^{17}$ and in ideal heads ${ }^{18}$.

Of the Hispanic heads with separately worked segments of hair, no other example is known with a tenon at the back made from the same piece of marble. These heads are not common in other provinces of the Empire either ${ }^{19}$.

15 Inan and Rosenbaum (1979: 341-343, no. 342, fig. 250). A more recent study can be found in Hirst and Salapata (2004: 114, figs. 11-14).

16 See supra n. 15.

17 For an example of a male portrait with a separately worked segment of hair: Gauckler, 1910: 402, fig. 8; see most recently Papini (2019: 174) with previous literature.

18 See for example Despinis (1975: 30-31, figs. 27-28), Scholl (1995: 44-45, F7, fig. 26), De Angelis (2002: 298-299) and Knoll and Vorster (2011: 232237, no. 28).

19 In addition to the technique seen in the head from Italica, Roman heads with separate hair segments were made in other ways. The four most usual techniques were: a) both parts smooth and without tenons (see for example Koppel, 1985: 14-15, no. 2, fig. 2; Sande, 1991: 32-34, no. 19, fig. 19; Despinis et al., 2003: 178-180, no. 285, figs. 878-883; Garriguet, 2006: 152, fig. 3; Zanker, 2016: 214-216, no. 80); b) both parts smooth with metal tenons (see for example Imdahl and Kunisch, 1979: 54-65; Fittschen and Zanker, 1983: 24-25, no. 24, fig. 33; 81, no. 109 , fig. 137 ; Bonanno, 1997: 59-61, fig. 18; Smith, 2006: 286, no. 200, figs. 134-135; Márquez, 2012: 206-211, no. 1, figs. 1-5; Schäfer, 2015: 721-727, nos. 2-3, figs. 2a-f and $3 \mathrm{a}-\mathrm{d})$; c) the opposite way to the case study, i.e., tenon in the hair segment and socket in the back part of the head (see for example Gauckler, 1910: 394, no. 2, figs. 4 and 5; Sensi, 1984/1985: 237-238, no. 5, fig. 21; Fittschen and Zanker, 1985: 3-6, no. 3, fig. 6; Koppel, 1985: 81, no. 106, figs. 41-42; Hirst and Salapata, 2004: 147, figs. 8-10; Smith, 2006: 179-180, no. 51,

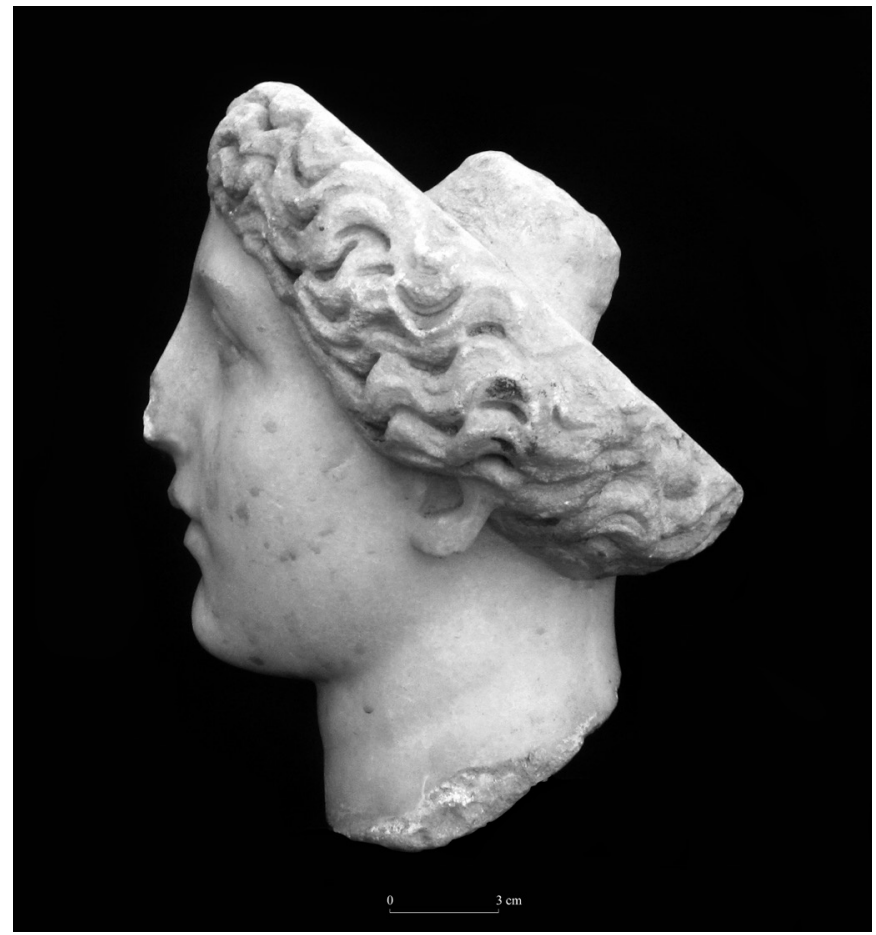

FIG. 4. Female head from Italica: left side.

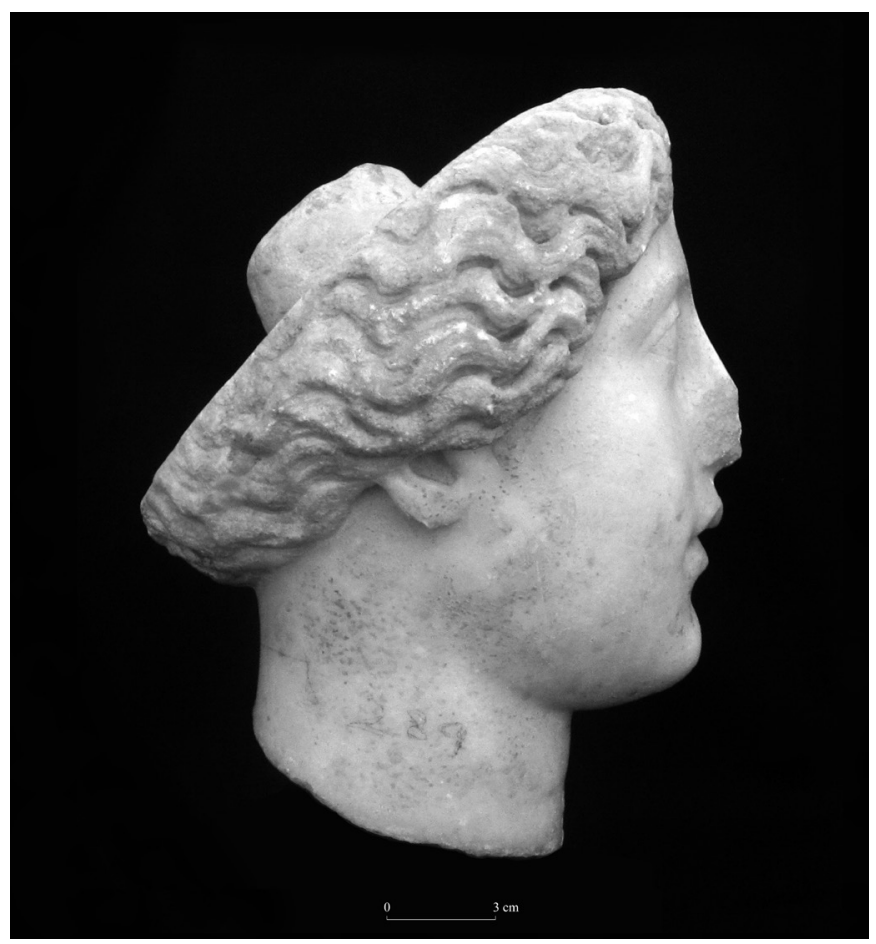

FIG. 5. Female head from Italica: right side. 


\begin{tabular}{|c|c|c|c|c|}
\hline & Chronology & TYPE OF PORTRAIT & LOCATION & REFERENCES \\
\hline $\mathrm{a}$ & Julio-Claudian & $\begin{array}{l}\text { Imperial portrait of } \\
\text { Augustus }\end{array}$ & $\begin{array}{l}\text { Vicenza, Museo Civico } \\
\text { (Inv. no. E I-44) }\end{array}$ & $\begin{array}{l}\text { Galliazzo, 1976: 100-103; Boschung, 1993: } \\
\text { 191-192, no. 203, fig. } 125 \text {. }\end{array}$ \\
\hline $\mathrm{b}$ & \multirow{6}{*}{ Antonine } & $\begin{array}{l}\text { Imperial portrait of } \\
\text { Trajan }\end{array}$ & $\begin{array}{l}\text { Avignon, Musée Calvet } \\
\text { (Inv. no. G. } 167 \text { A) }\end{array}$ & Rosso, 2006: 394-396, no. 162, fig. $127 \mathrm{a}-\mathrm{b}$. \\
\hline $\mathrm{c}$ & & $\begin{array}{l}\text { Imperial portrait of } \\
\text { Antinous } \\
\end{array}$ & $\begin{array}{l}\text { Rome, Auditorium di Mecenate, } \\
\text { Magazzino (without Inv. no.) } \\
\end{array}$ & Meyer, 1991: 51, fig. 31, 2, 4-5. \\
\hline $\mathrm{d}$ & & $\begin{array}{l}\text { Imperial portrait of } \\
\text { Antinous (Fig. 7) } \\
\end{array}$ & $\begin{array}{l}\text { Rome, Villa Adriana, Cento } \\
\text { Camerelle (Inv. no. } 598 \text { and 45323) }\end{array}$ & Ojeda, 2018b: 304, no. 316. \\
\hline $\mathrm{e}$ & & Private portrait & Private collection (without Inv. no.) & See supra n. 15. \\
\hline $\mathrm{f}$ & & \begin{tabular}{|l|} 
Imperial portrait of \\
Marcus Aurelius \\
\end{tabular} & $\begin{array}{l}\text { Bloomington, Indiana Univ. Museum } \\
\text { of Art (Inv. no. 74.145) }\end{array}$ & Albertson, 2004: 270, figs. 18-19. \\
\hline $\mathrm{g}$ & & $\begin{array}{l}\text { Imperial portrait of } \\
\text { Crispina }\end{array}$ & $\begin{array}{l}\text { Missouri, Museum of Art and } \\
\text { Archaeology, Univ. of Missouri- } \\
\text { Columbia (Inv. no. 74.145) }\end{array}$ & $\begin{array}{l}\text { Soren, 1975: 21-24, figs. } 1-3 \text {; Fittschen, } \\
\text { 1982: 85, no. 5, fig. 51, } 2 \text {. }\end{array}$ \\
\hline $\mathrm{h}$ & \multirow{3}{*}{ Severan } & Private portrait of a Vestal & $\begin{array}{l}\text { Rome, Antiquario Forense } \\
\text { (Inv. no. 424491) }\end{array}$ & $\begin{array}{l}\text { Mekacher, 2006: 220-221, p10, figs. 76-77, } \\
\text { 80-81. }\end{array}$ \\
\hline $\mathrm{i}$ & & \begin{tabular}{|l} 
Imperial portrait of \\
Septimius Severus
\end{tabular} & $\begin{array}{l}\text { Rome, Museo Nazionale Romano } \\
\text { (Inv. no. 193) }\end{array}$ & See supra n. 17. \\
\hline $\mathrm{j}$ & & Private portrait & $\begin{array}{l}\text { Munich, Antiquarium } \\
\text { (Inv. no. P. I 107) }\end{array}$ & $\begin{array}{l}\text { Weski and Frosien-Leinz, 1987: 171-172, } \\
\text { no. 49, fig. 89; 101, fig. 31. }\end{array}$ \\
\hline
\end{tabular}

Fig. 6. Table with compilation of Roman heads prepared to receive socketed segments of hair.

I only know of some examples, which I present in chronological order in a table (Fig. 6) ${ }^{20}$.

From the table it can be inferred that the heads prepared to receive these socketed segments of hair do not display a uniform sculpting technique.

figs. 46-47; Gercke and Zimmermann-Elseify, 2007: 266268, no. 86; Knoll and Vorster, 2013: 275-284, no. 63 and 435-439, no. 101; Zanker, 2016: 84-85, no. 26); and d) joint with an elongated horizontal tenon for a hair segment possibly of wood or marble (Despinis, 1975: 53; Goette, 2018: 77-81; see for example Rosenbaum, 1960: 68, no. 79, fig. 49, 3-4; Despinis, 1975: 30-31, figs. 27-28 and 32, figs. 32-35; Chamay et al., 1982: 154-157).

20 The list does not include a female portrait from Béziers (Balty and Cazes, 1995: 104-111, no. 9, figs. 99, 102 and 105-106; Boschung, 2002: 59, no. 13.9; Rosso, 2006: $357-359$, no. 128, fig. 102) because it cannot be ruled out that the tenon at the back was made in modern times to hold the restorations of the lost parts. Nor does it include heads made from two pieces, when they have been conserved together and I do not know of any descriptions or photographs of how they were assembled. See for example Sande, 1991: 74-75, no. 60, fig. 59; De Angelis, 2002: 298299. Of all the sculptures in the list only Case i) conserves the two pieces that formed the portrait. There are similar tenons and sockets in the 'halbierte Köpfe' (see the examples in Fittschen, 2019: 8-9, fig. 8, no. 1 and fig. 10, no. 3) and in the Roman portraits with 'Perücken' (see supra nn. 13-14. Fittschen, 2005: 87-88, n. 13).
Although they nearly all possess a square or rectangular tenon or socket, the head from Italica and the one in the Museo Nazionale Romano have a round tenon. Similarly, the cross-sections are not identical. In some instances, they are vertical or nearly-vertically diagonal, as in Cases a-e, $\mathrm{g}, \mathrm{h}$ and $\mathrm{j}$. However, in Case $\mathrm{f}$ and the head from Italica, they are totally diagonal, while in Case i it is practically horizontal.

The long chronological spread of the heads in the table, from the Julio-Claudian age to the Severan dynasty, does not allow the female head from Italica to be dated solely by its use of the separate hair segment technique ${ }^{21}$. However, four reasons can be put forward to support a date in the second quarter of the $2^{\text {nd }}$ century AD.

The first is that the hairstyle and the way of sculpting it find very close parallelisms in the iconography of the Haupttypus of Vibia Sabina ${ }^{22}$. This type was in use from AD 128 to 138 (Fittschen and Zanker, 1983: 11). An example where this similarity

21 The opposite occurs in the case of portraits with 'Perücken', because they were all made between $\mathrm{AD} 160$ and 220; see Fittschen, 2005: 90.

22 On the types of portraits of Sabina, see the works of Fittschen and Zanker (1983: 10-12) and Fittschen (2000: 507, n. 6; 2004: 112, n. 5). 


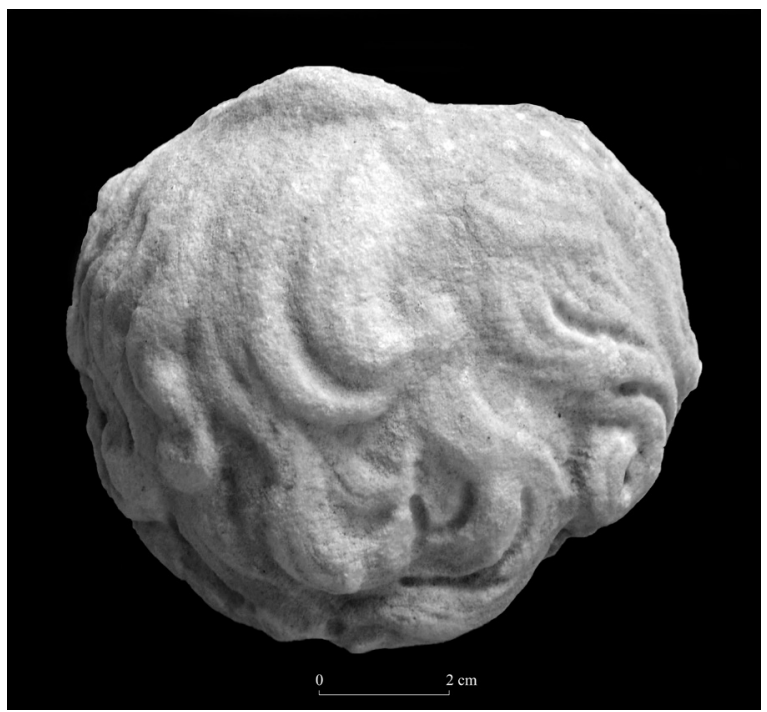

almost bulging eyes. A very similar way to represent eyes is used in the Type I portraits of Marcus Aurelius $^{24}$, whose prototype must have been made in around AD 138 (Fittschen, 1999: 20).

The third is that the Italica head closely resembles the representation of Hispania found in the Hadrianeum in Rome ${ }^{25}$, securely dated in $\mathrm{AD} 140^{26}$.

The fourth reason is that another head from Italica used a similar technique. This is a portrait of Marcus Aurelius which was also prepared at the back to receive a separately worked hair segment (Figs. 8-9). In this case, the sculptor did not carve a tenon, but a square socket surrounded by a series of incisions to improve the adherence of the missing attachment (León, 2001: 316-319, no. 97). This portrait was also made in the second quarter of the $2^{\text {nd }}$ century $\mathrm{AD}$. It corresponds to the Type II, variant d, of the Marcus Aurelius portraits, which can be dated between AD 147 and 151 (Fittschen, 1999: 24-25). The use of a similar attachment and the chronological coincidence support the proposed date for the ideal female head from Italica. It even suggests that both sculptures may have been carved in the same workshop ${ }^{27}$.

\section{Final remarks}

It is possible that some researchers might be tempted to identify the head from Italica as a highly idealised portrait of Sabina, as has occurred in other $\operatorname{cases}^{28}$. The resemblance to the empress and

FIG. 7. Segment of hair from a portrait of Antinous: top and underside; height $10 \mathrm{~cm}$; Hadrian's villa, Cento Camerelle 598/45323 (courtesy T. Nogales and P. León).

can easily be observed is a portrait of the empress in the Musei Vaticani ${ }^{23}$.

The second is that the sculptor marked the iris with an incision, indicated the pupil by a trepanation in the form of a pelte and represented large,

23 Carandini, 1969: 189-191, no. 55, figs. 235-236; Fittschen and Zanker, 1983: 10, no. 10, replica 7. See for another parallel Wegner, 1956: 129, figs. 45a and 47a.

24 See for example Fittschen, 1999: 13, A1, fig. 1; 13, A5, fig. 8b; 13, A7, fig. 5; 14, A10, fig. 8a; 14, A14, fig. 11; 14, A16, fig. 13a-b; 15, A26, fig. 19c-d.

25 Sapelli, 1999: 64-65, no. 19.

26 CApitol. Ver. 3.

27 A third sculpture from Italica of similar chronology may have had a separately worked hair segment (León, 1995: 138-139, no. 45). Unfortunately I have not been able to examine the back of the object and do not know of any photographs of that detail.

28 Examples of similar cases are cited by Fittschen and Zanker (1983: 12, n. 4). 
arguments, but not determinant ${ }^{29}$. Bearing in mind that the features of the head are very impersonal and the hairstyle lacks typical elements of a fashion characteristic of a particular time $e^{30}$, it is more likely to be an ideal head ${ }^{31}$.

Should this hypothesis be correct, the head would form part of the ensemble of ideal female heads from Italica made in the second quarter of the $2^{\text {nd }}$ century $\mathrm{AD}^{32}$. Its inclusion in this group is important in two ways. First, it attests the presence of ideal statues in the residential district of Italica, and second, it shows that the workshop, or workshops, that supplied the Nova Urbs with ideal sculptures employed the technique based on separate hair segments. This may seem an insignificant detail, but it is not. Only to the extent that we are able to detect these small characteristics of the workshops will it be possible to determine one day how many workshops functioned in Italica ${ }^{33}$, what their sculptural production was like, how long they were in operation and their area of influence ${ }^{34}$. We still known very little about these points, but a systematic study of separately worked segments of hair in Hispania may in the future cast some light on these questions.

29 Although all the examples in the present list with the same technique for joining the head - a socket in the attachment and tenon in the head-are portraits, separately worked hair segments have also been documented in ideal statues (see supra n. 18).

30 The conserved hair can also be found relatively frequently in heads of goddesses. Some examples also from Italica in León, 1995: 126-129, no. 40 and 146-149, no. 48; Rodríguez Oliva, 2009: 88, fig. 78.

31 The problem is not exclusive to this sculpture. There are other female heads where it is not possible to determine whether they are portraits or ideal statues. For some examples and their correct methodological treatment: Fittschen, 1982: 79-80, n. 43; Fittschen and Zanker, 1983: 12, n. 4; Fittschen, 2000: 508, n. 10.

32 See supra n. 30.

33 On the workshops in Italica: León, 1995: 25-29; Ojeda, 2013: 375 .

34 On the possibility that workshops in Italica supplied Munigua: Hertel, 1993: 100-101 and Ojeda, 2018c: 695.

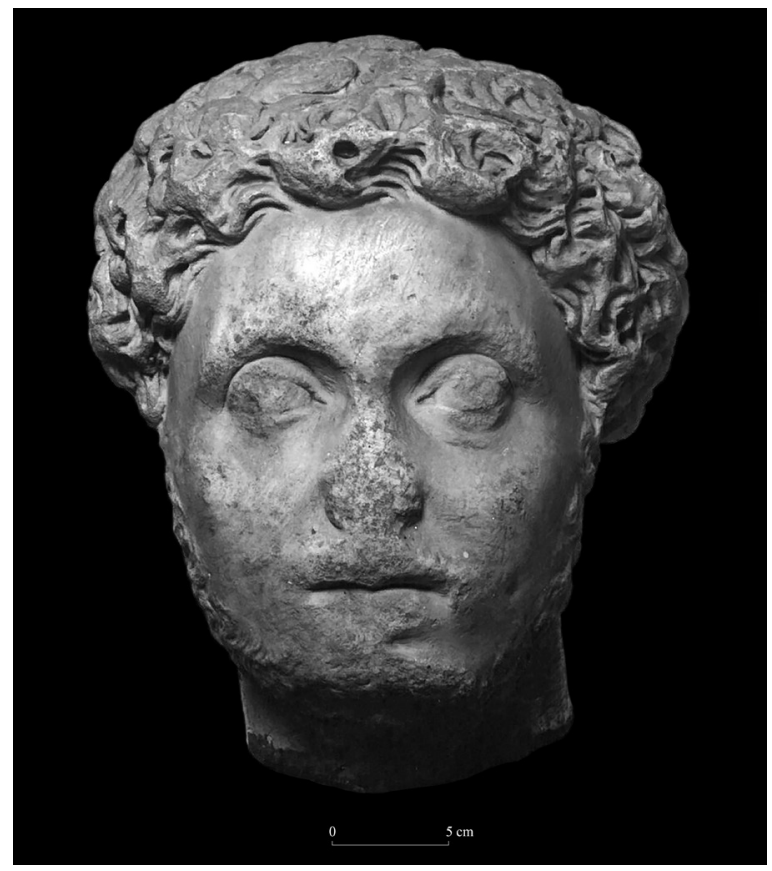

Fig. 8. Portrait of Marcus Aurelius from Italica: front; height $30 \mathrm{~cm}$; distance from chin to cranium $28 \mathrm{~cm}$; Archaeological Museum of Seville 143-1 (courtesy P. León).

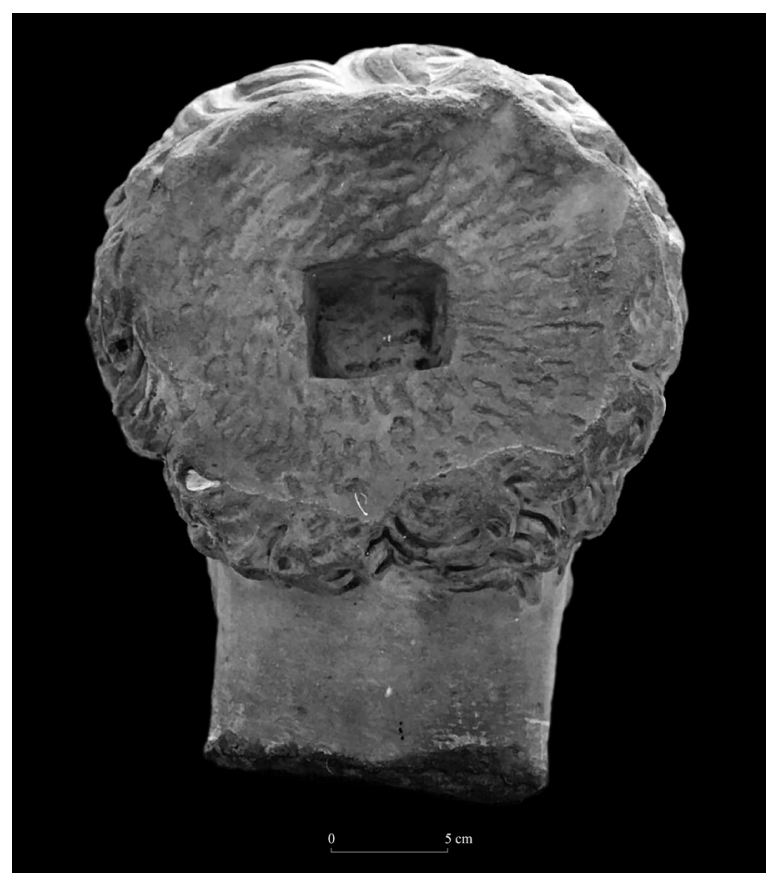

FIG. 9. Back of the portrait of Marcus Aurelius from Italica (courtesy P. León). 


\section{Bibliography}

Ackers, H. I. (2019): “The representation of wigs in Roman female portraiture of the Late 2 nd to 3 rd century $A D ", B A B e s c h, 94$, pp. 211-234.

Adam, S. (1966): The Technique of Greek Sculpture in the Archaic and Classical Periods. The British School of Archaeology at Athens, Suppl. 3. London: Thames $\&$ Hudson.

Albertson, F. C. (2004): "The Creation and Dissemination of Roman Imperial Portrait Types: The Case of Marcus Aurelius Type Iv", Jahrbuch des Deutschen Archäologischen Instituts, 119, pp. 259-306.

Balty, J. Ch. and Cazes, D. (1995): Portraits impériaux de Béziers. Toulouse: Musée Saint-Raymond.

Bonanno, M. (1997): "Due ritratti di età antonina nel Museo Archeologico di Tebe". In Bouzek, J. and Ondrejovì, I. (eds.): Roman Portraits. Artistic and Literary. Mainz: von Zabern, pp. 57-61.

Boschung, D. (1993): Die Bildnisse des Augustus. Berlin: Gebr. Mann.

Boschung, D. (2002): Gens Augusta. Untersuchungen zu Aufstellung, Wirkung und Bedeutung der Statuengruppen des julisch-claudischen Kaiserhauses. Mainz: von Zabern.

Caballos, A.; Marín, J. and Rodríguez, J. M. (1999): Itálica Arqueológica. Sevilla: Univ. de Sevilla.

Carandini, A. (1969): Vibia Sabina. Funzione politica, iconografia e il problema del classicismo adrianeo. Firenze: Olschki.

Chamay, J.; Frel, J. and Maier, J.-L. (1982): Le monde des Césars. Genève: Musée d'art et d'histoire de Genève.

Claridge, A. (1990): "Ancient Techniques of Making Joins in Marble Statuary". In True, M. and PodaNY, J. (eds.): Marble. Art Historical and Scientific Perspectives on Ancient Sculpture. Malibu: J. Paul Getty Museum, pp. 135-162.

Crawford, J. R. (1917): "Capita Desecta and Marble Coiffures", Memoirs of the American Academy in Rome, 1, pp. 103-119.

De Angelis, M. (2002): "Statua di Dioniso". In De Angelis, M. (ed.): Scultura antica in Palazzo Altemps. Milano: Electa, pp. 298-299.

Despinis, G. (1975): Aкрó $\lambda 1 \theta \alpha$. Athens: Ipiresia Dimosievmaton.

Despinis, G.; Stephanidou-Tiveriou, Th. and

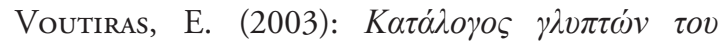

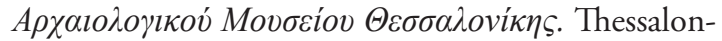
iki: National Bank Cultural Foundation.

Fittschen, K. (1982): Die Bildnistypen der Faustina minor und die Fecunditas Augustae. Göttingen: Vandenhoek \& Ruprecht.

Fittschen, K. (1999): Prinzenbildnisse antoninischer Zeit. Mainz: von Zabern.

Fittschen, K. (2000): "Nicht Sabina”, Archäologischer Anzeiger, 2000, pp. 507-514.

Fittschen, K. (2004): "Römerin oder Griechin? Priesterin oder Königin? Zum bronzenen Bildnis einer unbekannten Frau in Basel”, Antike Kunst, 47, pp. 112-124.

Fittschen, K. (2005): "Die vertauschte Perücke”. In Ganschow, Th.; Steinhard, M.; Berges, D. and FröHlich, Th. (eds.): Otium. Festschrift für Volker Michael Strocka. Remshalden: Greiner, pp. 87-95.

Fittschen, K. (2019): Halbierte Köpfe? Wiesbaden: Harrassowitz.

Fittschen, K. and Zanker, P. (1983): Katalog der römischen Porträts in den Capitolinischen Museen und den anderen kommunalen Sammlungen der Stadt Rom III. Mainz: von Zabern.

Fittschen, K. and Zanker, P. (1985): Katalog der römischen Porträts in den Capitolinischen Museen und den anderen kommunalen Sammlungen der Stadt Rom I. Mainz: von Zabern.

Galliazzo, V. (1976): Sculture greche e romane del Museo Civico di Vicenza. Treviso: Marton.

García-Entero, V. (2005): Los balnea domésticos -ámbito rural y urbano- en la Hispania romana. Madrid: CSIC.

García y Bellido, A. (1960): Colonia Aelia Augusta Italica. Madrid: CSIC.

Garriguet, J. A. (2006): “¿Provincial o foráneo? Consideraciones sobre la producción y recepción de retratos imperiales en Hispania”. In VAQUerizo, D. and Murillo, J. F. (eds.): El concepto de lo provincial en el mundo antiguo. Homenaje a la Prof. Pilar León. Córdoba: Univ. de Córdoba, pp. 143-194.

Gauckler, P. (1910): "Nouvelles découverts dans le sanctuaire syrien du Janicule", Comptes rendus des séances de l'Académie des Inscriptions et Belles-Lettres, 54, pp. 378-408.

Gercke, P. and Zimmermann-Elseify, N. (2007): Antike Steinskulpturen und Neuzeitliche Nachbildungen in Kassel. Bestandskatalog. Mainz: von Zabern.

Goette, H. R. (2018): “Zu einigen 'technischen' Charakteristika kaiserzeitlicher Portraits aus griechischen Werkstätten”. In Karanastasi, P.; 
Stefanidou-Tiveriou, Th. and Damaskos, D.

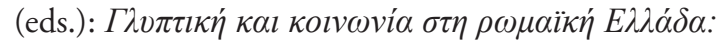

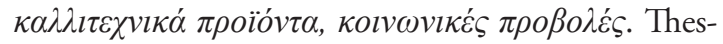
saloniki: University Studio Press, pp. 75-82.

Hertel, D. (1993): “Die Skulpturen”. In Blech, M.; Hauschild, Th. and Hertel, D. (eds.): Mulva III. Mainz: von Zabern, pp. 35-108.

Hirst, M. and Salapata, G. (2004): "Private Roman Female Portraits: Reworked or Pieced?”, BABesch, 79, pp. 143-158.

Imdahl, M. and Kunisch, N. (1979): Plastik. Antike und moderne Kunst der Sammlung Dierichs in der Ruhm-Universität Bochum. Bonn: Habelt.

Inan, J. and Rosenbaum, E. (1979): Römische und Frühbyzantinische Porträtplastik aus der Türkei. Neue Funde. Mainz: von Zabern.

Knoll, K. and Vorster, Ch. (2011): Katalog der antiken Bildwerke II, 1. München: Hirmer.

Knoll, K. and Vorster, Ch. (2013): Katalog der antiken Bildwerke III. München: Hirmer.

Koppel, E. M. (1985): Die römischen Skulpturen von Tarraco. Berlin: de Gruyter.

León, P. (1992): "Zur Neustadt von Italica”. In Schalles, H.-J.; Von Hesberg, H. and Zanker, P. (eds.): Die römische Stadt im 2. Jahrhundert N. Chr. Der Funktionswandel des öffentlichen Raumes. Köln: Rheinland-Verlag, pp. 87-97.

LeÓn, P. (1995): Esculturas de Italica. Sevilla: Fund. El Monte.

León, P. (2001): Retratos romanos de la Bética. Sevilla: Fund. El Monte.

MaÑas, I. (2011): Mosaicos romanos de Itálica II. Madrid: CSIC.

Márquez, C. (2012): "Dos nuevos retratos de Augusto en la provincia de Córdoba”, Romula, 11, pp. 205221.

Mekacher, N. (2006): Die vestalischen Jungfrauen in der römischen Kaiserzeit. Wiesbaden: Reichert.

Meyer, H. (1991): Antinoos. Die archäologischen Denkmäler unter Einbeziehung des numismatischen und epigraphischen Materials sowie der literarischen Nachrichten. Ein Beitrag zur Kunst- und Kulturgeschichte der hadrianisch-frühantoninischen Zeit. München: Fink.

OJedA, D. (2013): "Un torso ataviado con la piel de un macho cabrío procedente de Italica”. In Hidalgo, R. and León, P. (eds.): Roma, Tibur, Baetica. Investigaciones adrianeas. Sevilla: Univ. de Sevilla, pp. 369-375.

Ediciones Universidad de Salamanca / ®ఠ
OJEDA, D. (2018a): "Anstückungen an kaiserzeitlichen Idealskulpturen. Zu drei aus der Baetica stammenden Statuen des Mars", Archäologischer Anzeiger, 2018, pp. 193-208.

OJEDA, D. (2018b): "Estatuas-retrato". In León, P. and Nogales, T. (eds.): Villa Adriana. Escultura de los almacenes. Roma: L'Erma di Bretschneider, pp. 249310.

OJeda, D. (2018c): “¿Hispania, Venus, ninfa o sirena? Sobre una estatua femenina procedente de Munigua”. In Márquez, C. and Ojeda, D. (eds.): Escultura romana en Hispania VIII. Córdoba: Univ. de Córdoba, pp. 691-703.

OjedA, D. (2019): "Esculturas y relieves históricos". In SÁnchez, E. and Bustamante, M. (eds.): $A r$ queología Romana en la Península Ibérica. Granada: Univ. de Granada, pp. 843-854.

Papini, M. (2019): I reperti scultorei dalle 'Terme di Elagabalo'. Il ritrovamento. Il restauro. L'edizione. Roma: Quasar.

Parladé, A. (1934): Excavaciones en Itálica. Campañas de 1925 a 1932. Madrid: Tipografía de Archivos.

Peña, A. y Rodero, S. (2004): "Un conjunto de esculturas de pequeño formato procedente de Italica (Santiponce, Sevilla)", Romula, 3, pp. 63-102.

Peña, A. (2005): "Imitaciones del Forum Augustum en Hispania: el ejemplo de Italica”, Romula, 4, pp. 137162.

Rodríguez Oliva, P. (2009): "La escultura ideal". In León, P. (ed.): Arte Romano de la Bética II. Escultura. Sevilla: Fund. Focus-Abengoa, pp. 41-151.

Rosenbaum, E. (1960): A Catalogue of Cyrenaican Portrait Sculpture. London: oup.

Rosso, E. (2006): L'image de l'empereur en Gaule romaine. Portraits et inscriptions. Paris: Éditions du Comité des travaux historiques et scientifiques.

SAnde, S. (1991): Greek and Roman Portraits in Norwegian Collections. Roma: Giorgio Bretschneider.

Sapelli, M. (ed.) (1999): Provinciae Fideles. Il fregio del tempio di Adriano in Campo Marzio. Roma: Electa.

SCHÄFER, Th. (1996): "Gepickt und versteckt. Zur Bedeutung und Funktion aufgerauhter Oberflächen in der spätarchaischen und frühklassischen Plastik", Jahrbuch des Deutschen Archäologischen Instituts, 111, pp. 25-74.

SCHÄFER, Th. (2015): "Plastik aus Marmor". In SCHÄFER, Th.; Sснmidt, K. and Osanna, M. (eds.): Cossyra I. Die Ergebnisse der Grabungen auf der Akropolis von Pantelleria/S. Teresa. Der Sakralbereich. Rahden: Leidorf, pp. 771-763. 
Scholl, A. (1995): Die antiken Skulpturen in Farnborough Hall. Mainz: von Zabern.

SENSI, L. (1984/1985): "I ritratti romani di Spoleto", Annali della Facoltà di lettere e filosofia, 22, pp. 229276.

Sмith, R. R. R. (2006): Roman Portrait Statuary from Aphrodisias. Mainz: von Zabern.

Soren, D. (1975): "A Portrait of the Empress Crispina”, Muse, 9, pp. 21-24.

Stern, E. M. (1985): "Die Kapitelle der Nordhalle des Erechtheion", Mitteilungen des Deutschen
Archäologischen Instituts, Athenische Abteilung, 100, pp. 405-426.

Wegner, M. (1956): Hadrian. Plotina. Marciana. Matidia. Sabina. Berlin: Gebr. Mann.

Weski, E. and Frosien-Leinz, H. (1987): Das Antiquarium der Münchner Residenz. Katalog der Skulpturen. München: Hirmer.

ZANker, P. (2016): Roman Portraits: Sculptures in Stone and Bronze in the Collection of the Metropolitan Museum of Art. New York: MMA. 